\title{
Zalecenia metodyczne dotyczące oceny mutacji genu EGFR oraz rearanżacji genu $A L K$ w kwalifikacji chorych na niedrobnokomórkowego raka płuca do terapii ukierunkowanych molekularnie
}

\author{
Paweł Krawczyk 1, 2,3, Joanna Chorostowska-Wynimko' ${ }^{2,4}$, Rafał Dziadziuszko ${ }^{5,6}$, \\ Jacek Jassem ${ }^{5,6}$, Maciej Krzakowski ${ }^{7,8}$, Renata Langfort' ${ }^{9}{ }^{10}$, Elżbieta Puacz ${ }^{11}$, \\ Bartosz Wasąg ${ }^{3,12}$, Kamila Wojas-Krawczyk ${ }^{1}$
}

Zalecenia równolegle publikowane są w Onkologii w Praktyce Klinicznej i w Pneumonologii i Alergologii Polskiej

Badania molekularne mające na celu wykrycie mutacji genu EGFR i rearanżacji genu ALK wykonuje się rutynowo w zaawansowanym niedrobnokomórkowym raku płuca (NDRP) w celu właściwej kwalifikacji chorych do terapii ukierunkowanych molekularnie. Przedstawiamy polskie zalecenia metodyczne w prowadzeniu diagnostyki molekularnych nieprawidłowości w genach EGFR i ALK. Zalecenia te opisują szczegółowo wskazania kliniczne do wykonania testów, rodzaj materiału oraz sposób postępowania z nim, a także wymagania stawiane laboratoriom wykonującym diagnostykę molekularną.

Methodological recommendations for the diagnostics of EGFR gene mutations and ALK gene rearrangement in the selection of non-small-cell lung cancer patients to molecularly targeted therapies

Testing for EGFR gene mutations and ALKgene rearrangement is routinely used in advanced non-small-cell lung cancer for adequate patient selection to molecularly targeted therapies. We present Polish methodological recommendations for molecular analysis of EGFR and ALK genetic abnormalities. Recommendations specify clinical indications for testing, sample types and handling, as well as requirements for laboratories performing molecular diagnostics.

NOWOTWORY Journal of Oncology 2014; 64, 4: 336-342

Słowa kluczowe: niedrobnokomórkowy rak płuca, mutacje genu EGFR, rearanżacja genu ALK, genetyczne testy diagnostyczne

Key words: non-small-cell lung cancer, EGFR gene mutations, ALK gene rearrangement, genetic diagnostic tests

\footnotetext{
${ }^{1}$ Pracownia Immunologii i Genetyki Katedry i Kliniki Pneumonologii, Onkologii i Alergologii Uniwersytetu Medycznego w Lublinie ${ }^{2}$ Polskie Towarzystwo Chorób Płuc

${ }^{3}$ Polskie Towarzystwo Genetyki Człowieka

${ }^{4}$ Zakład Genetyki i Immunologii Klinicznej Instytutu Gruźlicy i Chorób Płuc w Warszawie

${ }^{5}$ Katedra i Klinika Onkologii i Radioterapii Gdańskiego Uniwersytetu Medycznego

${ }^{6}$ Polskie Towarzystwo Onkologiczne

${ }^{7}$ Klinika Nowotworów Płuca i Klatki Piersiowej Centrum Onkologii — Instytutu im. Marii Skłodowskiej-Curie w Warszawie ${ }^{8}$ Polskie Towarzystwo Onkologii Klinicznej

${ }^{9}$ Zakład Patomorfologii, Instytut Gruźlicy i Chorób Płuc

${ }^{10}$ Polskie Towarzystwo Patologów

${ }^{11}$ Krajowa Izba Diagnostów Laboratoryjnych

${ }^{12}$ Katedra i Zakład Biologii i Genetyki Gdańskiego Uniwersytetu Medycznego
} 


\section{Wprowadzenie}

Wytyczne prezentują opinie polskich ekspertów, dysponujących znaczącym doświadczeniem w zakresie diagnostyki patomorfologicznej i molekularnej niedrobnokomórkowego raka płuca (NDRP). Wraz z szybkim rozwojem ukierunkowanej molekularnie farmakoterapii chorych na NDRP znacząco wzrasta w Polsce liczba diagnostycznych badań genetycznych, służących prawidłowej kwalifikacji chorych do leczenia. Wytyczne te mają na celu wnikliwe omówienie metodyczne wszystkich etapów właściwie prowadzonej diagnostyki.Zzałożenia mają umożliwić eliminację niewłaściwych praktyk laboratoryjnych, skutkujących błędnym wynikiem badania genetycznego lub opóźnieniem procesu diagnostycznego.

Zgodnie z obwieszczeniem Ministra Zdrowia w sprawie wykazu refundowanych leków, środków spożywczych specjalnego przeznaczenia żywieniowego oraz wyrobów medycznych ( $\mathrm{z} 1$ marca 2014 r.) ukierunkowane molekularnie leczenie chorych na NDRP prowadzone w ramach programu lekowego obejmuje stosowanie dwóch inhibitorów kinazy tyrozynowej (IKT) receptora czynnika wzrostu naskórka (EGFR, epidermal growth factor receptor), którymi są erlotynib i gefitynib [1]. Oba leki mogą być stosowane w 1. i 2. linii leczenia u chorych na niektóre podtypy morfologiczne NDRP w stadium miejscowego zaawansowania (chorzy poza możliwościami leczenia radykalnego) lub uogólnienia z obecnością mutacji aktywującej w genie EGFR [2].W najbliższej przyszłości spodziewane jest poszerzenie możliwości leczenia ukierunkowanego molekularnie u chorych na miejscowo zaawansowanego i uogólnionego NDRP o leki zarejestrowane w Unii Europejskiej, ale nieobjęte dotąd systemem refundacji w Polsce. Należą do nich: nieodwracalny IKT EGFR, HER2 i HER4 - afatynib oraz inhibitor kinazy tyrozynowej ALK (anaplastic lymphoma kinase) - kryzotynib.

\section{Wskazania kliniczne do oceny mutacji w genie EGFR i rearanżacji genu $A L K$ u chorych na NDRP}

A. Rekomendacja: Potwierdzenie obecności mutacji w genie EGFR lub rearanżacji genu $A L K$ w komórkach nowotworowych jest kluczowym kryterium kwalifikacji chorych na NDRP do terapii ukierunkowanych molekularnie z wykorzystaniem IKT EGFR lub IKT ALK [2].

B. Rekomendacja: Decyzję o wykonaniu badania genetycznego u chorego na NDRP powinien podjąć lekarz onkolog lub pulmonolog na podstawie indywidualnej oceny stanu chorego oraz wskazań klinicznych do leczenia ukierunkowanego molekularnie. Oznaczenie mutacji genu EGFR należy wykonać u chorych z rozpoznaniem NDRP o innym utkaniu niż płaskonabłonkowe, natomiast badanie rearanżacji genu $A L K$ - u chorych z rozpoznaniem raka gruczołowego lub zawierającego komponent utkania gruczołowego. Stopień zróżnicowania histologicznego (grade) nie ma wpływu na wskazania do diagnostyki molekularnej [3-8].
Nie zaleca się wykonania badania genetycznego, jeśli w ocenie histopatologicznej wycinków guza uwidoczniono jedynie komórki raka płaskonabłonkowego, raka drobnokomórkowego płuca lub rakowiaka. W sytuacji, gdy na podstawie standardowego barwienia hematosylina + eozyna $(\mathrm{H}+\mathrm{E})$ nie można określić podtypu NDRP, konieczne jest wykonanie barwień histochemicznych (na obecność śluzu w komórkach raka) i/lub immunohistochemicznych (IHC). Wskazane jest oznaczenie ekspresji co najmniej dwóch markerów: TTF-1, którego obecność wskazuje na różnicowanie gruczołowe raka, i p63 lub p40, którego ekspresja przemawia za różnicowaniem płaskonabłonkowym raka.W przypadku preparatów cytologicznych badanie IHC powinno każdorazowo poprzedzać kwalifikację do diagnostyki genetycznej [3-8].

Dopuszczalne jest wykonanie badania molekularnego w kierunku mutacji genu EGFR, jeśli ustalenie typu morfologicznego NDRP nie jest możliwe (NOS, not othervise specified) [5-8].

C. Rekomendacja: Kryteria demograficzne, takie jak płeć, rasa i wywiad w kierunku palenia tytoniu, nie mają wpływu na wskazania do poszukiwania mutacji genu EGFR i rearanżacji genu $A L K$ u chorych na NDRP. Dopuszczalne jest uwzględnienie wywiadu odnośnie palenia tytoniu, jeśli diagnostyka prowadzona jest na podstawie materiału tkankowego ubogokomórkowego lub materiału cytologicznego, w którym nie wykluczono obecności komponentu gruczołowego (NDRP NOS) [6-8].

D. Rekomendacja: Materiał tkankowy pochodzący z guza pierwotnego i materiał tkankowy pochodzący z przerzutów NDRP należy traktować jako równowartościowe dla oznaczenia mutacji genu EGFR i rearanżacji genu ALK. Nie ma uzasadnienia dla równoczesnego badania kilku wycinków z jednego nowotworu [6-8].

\section{Zasady prowadzenia diagnostyki molekularnej w kierunku mutacji genu EGFR i rearanżacji genu $A L K$}

A. Rekomendacja: Zaleca się, aby lekarz onkolog lub pulmonolog kierujący do oceny patomorfologicznej materiał pochodzący od chorego z podejrzeniem miejscowo zaawansowanego lub uogólnionego NDRP — stadium IIIB i IV według 7. edycji klasyfikacji guz-węzeł-przerzuty (TNM, tumor-nodes-metastases) $[9,10]$ - pisemnie zlecał kontynuowanie diagnostyki w zakresie badań genetycznych, o ile uzasadnia to rozpoznanie morfologiczne, objętość i jakość dostępnego materiału.W tym przypadku zaleca się, aby patomorfolog w momencie ustalenia rozpoznania mikroskopowego podejmował decyzję o ewentualnym kontynuowaniu diagnostyki genetycznej w kierunku mutacji genu EGFR i rearanżacji genu $A L K$. W razie braku stosownego zalecenia lekarskiego zabezpieczony materiał powinien być 
przekazany do badania genetycznego niezwłocznie po uzyskaniu pisemnego skierowania od lekarza prowadzącego [6-8].

Konieczne jest wykonanie badania genetycznego u chorych na mniej zaawansowane postacie NDRP w momencie nawrotu choroby lub w przypadku braku możliwości leczenia radyklanego, o ile rozważana jest kwalifikacja do leczenia ukierunkowanego molekularnie.

B. Rekomendacja: Zaleca się, aby w postępowaniu diagnostycznym w pierwszej kolejności ocenić mutację genu EGFR. Oznaczenie rearanżacji genu ALK u chorych z rozpoznaniem raka gruczołowego należy wykonać po uprzednim potwierdzeniu braku mutacji somatycznych w genie EGFR. Obecnie istnieje brak wystarczających dowodów klinicznych uzasadniających analizę innych markerów molekularnych u chorych na NDRP [6-8].

C. Rekomendacja: Czas oczekiwania na wynik oznaczenia mutacji genu EGFR i/lub rearanżacji genu $A L K$ nie powinien przekraczać 10 dni roboczych od momentu dostarczenia materiału tkankowego do laboratorium genetycznego. Zaleca się jednak, aby czas oczekiwania na wynik badania genetycznego wynosił maksymalnie 5 dni roboczych [6-8].

D. Rekomendacja: Zaleca się aby laboratoria, w których czas oczekiwania na oznaczenie mutacji genu EGFR i rearanżacji genu $A L K$ przekracza 10 dni roboczych, dostosowały swoje procedury i techniki badawcze do powyższych wymagań [6-8].

E. Rekomendacja: Czas przygotowania materiału archiwalnego przez pracownię patomorfologii i dostarczenia go do laboratorium genetycznego nie powinien przekraczać 3 dni od momentu otrzymania skierowania. Akceptowalne jest wydłużenie tego okresu w razie konieczności ponownej oceny morfologicznej materiału [6-8].

\section{Wymagania stawiane diagnostycznym laboratoriom genetycznym wykonującym badania mutacji genu EGFR i rearanżacji genu ALK}

A. Rekomendacja: Zasady funkcjonowania laboratoriów wykonujących diagnostykę genetycznych czynników predykcyjnych dla terapii ukierunkowanych molekularnie w chorobach nowotworowych muszą być zgodne z zapisami Ustawy z dnia 27 lipca 2001 roku o diagnostyce laboratoryjnej (wraz z późniejszymi zmianami) oraz Rozporządzeniem Ministra Zdrowia z dnia 21 stycznia 2009 roku, zmieniającym rozporządzenie w sprawie standardów jakości dla medycznych laboratoriów diagnostycznych i mikrobiologicznych (Załącznik nr 3) [11, 12]. Poniższe rekomendacje B-D uszczegółowiają zasady funkcjonowania laboratorium zawarte w Załączniku nr 3 do Rozporządzenia Ministra Zdrowia.
B. Rekomendacja: Badanie genetyczne może być wykonywane wyłącznie pod nadzorem diagnosty laboratoryjnego lub lekarza, który jest zatrudniony w pracowni wykonującej to badanie oraz: 1) posiada tytuł specjalisty medycznej genetyki laboratoryjnej i jest zatrudniony nieprzerwanie w pracowni wykonującej badania genetyczne lub 2) posiada co najmniej dwuletni staż pracy w laboratorium genetycznym i jest w trakcie specjalizacji z medycznej genetyki laboratoryjnej; 3) w ciągu ostatnich 5 lat jest zatrudniony nieprzerwanie w laboratorium genetycznym prowadzącym badania mutacji w genie EGFR i rearanżacji genu $A L K$.

C. Rekomendacja: Badanie mutacji w genie EGFR oraz rearanżacji genu $A L K$ jest rutynową procedurą oceny niedziedzicznych nieprawidłowości genetycznych w komórkach nowotworowych. Nie jest więc konieczne uzyskanie odrębnej świadomej zgody pacjenta na wykonanie badania genetycznego. Ogólna zgoda na przeprowadzenie badań diagnostycznych, w tym badania mutacji genu EGFR i rearanżacji genu $A L K$, powinna być uzyskiwana przy przyjęciu do szpitala i przechowywana razem z całą dokumentacją chorego.

D. Rekomendacja:Zaleca się, aby laboratoria genetyczne wykonujące diagnostykę mutacji genu EGFR i rearanżacji genu ALK prowadziły okresową wewnętrzną kontrolę jakości wykonywanych badań oraz uczestniczyły w programach zewnętrznej oceny jakości (EQA, external quality assessment) [12]. Polskie laboratoria genetyczne mają dostęp do programów EQA prowadzonych przez uznane międzynarodowe ośrodki badania jakości w diagnostyce genetycznej (np. European Molecular Quality Network, European Society of Pathology) i powinny posiadać certyfikaty jakości wydane przynajmniej przez jeden z nich.

E. Rekomendacja:Zaleca się opracowanie polskiego programu zewnętrznej kontroli jakości obejmującego badanie mutacji genu EGFR i rearanżacji genu $A L K$ w materiale od chorych na NDRP.

\section{Wymagania dotyczące technik oraz zakresu badania mutacji genu EGFR}

A. Rekomendacja: Badanie genetyczne w kierunku mutacji genu EGFR powinno być wykonywane jedynie w materiale zabezpieczonym odpowiednimi technikami: 1) fragmentach tkanek utrwalonych w formalinie i zatopionych w parafinie (materiał preferowany ze względu na stabilność, przydatny do badania genetycznego nawet po kilku latach od pobrania materiału); 2) świeżo pobranych fragmentach tkanek; 3) tkankach zamrożonych; 4) tkankach utrwalonych w alkoholu. Materiały utrwalone w inny sposób, zwłaszcza z zastosowaniem utrwalaczy zawierających związki metali ciężkich lub roztworów o właściwościach odwapniających i w środowisku kwaśnym, nie powinny być wykorzystywane do oceny 
mutacji genu EGFR. Zaleca się ścisłe przestrzeganie czasu utrwalania tkanek w 10-procentowym zbuforowanym roztworze formaliny, który powinien wynosić 6-48 godzin. Każde odstępstwo od rutynowych procedur laboratoryjnych, zwłaszcza zalecanego czasu utrwalania oraz metody zatapiania tkanek w parafinie, należy odnotować w raporcie patomorfologicznym ze względu na ich ewentualny wpływ na integralność DNA komórek nowotworowych [5-8].

B. Rekomendacja: Materiał cytologiczny, zwłaszcza utrwalony w postaci cytobloków lub jako rozmaz na szkiełku podstawowym, jest właściwy do analizy mutacji genu EGFR. Zawiesina komórek do sporządzenia cytobloku powinna być utrwalona w 10-procentowym zbuforowanym roztworze formaliny lub $w$ 70-procentowym roztworze etanolu przez 6-48 godzin. Zaleca się, aby laboratorium przeprowadziło walidację pełnej procedury opracowania materiału cytologicznego, w tym jego utrwalania i analizy genetycznej w kierunku mutacji genu EGFR [5-8, 13, 14].

C. Rekomendacja: Zaleca się, aby wybór reprezentatywnego materiału do oznaczenia mutacji genu EGFR był dokonywany przez patomorfologa. Konieczna jest ocena procentowej zawartości komórek nowotworowych i ognisk martwicy, a w przypadku preparatów cytologicznych także liczby komórek nowotworowych. Wskazane jest przygotowanie seryjnie skrojonych preparatów z bloczków parafinowych lub cytobloków według następującego schematu: pierwszy preparat grubości $3 \mu \mathrm{m}$, przeznaczony do oceny zawartości komórek nowotworowych w badanym materiale (barwienie hematoksyliną i eozyną - $\mathrm{H}+\mathrm{E}$ ); drugi preparat o grubości minimum 8-10 $\mu \mathrm{m}$, przeznaczony do izolacji DNA (w przypadku materiałów bogatokomórkowych dopuszcza się skrojenie kilku preparatów o grubości 8-10 $\mu \mathrm{m}$ ); preparaty trzeci i czwarty o grubości 3-5 $\mu \mathrm{m}$, przeznaczone do oceny rearanżacji genu $A L K$ [metodą fluorescencyjnej hybrydyzacji in situ (FISH, fluorescent in situ hybridization) i immunohistochemiczną (IHC, immunohistochemistry)], jeśli laboratorium używa tych metod do wstępnej diagnostyki rearanżacji genu $A L K$ ); piąty preparat o grubości $3 \mu \mathrm{m}$, przeznaczony do ponownej oceny zawartości komórek nowotworowych [6-8].

D. Rekomendacja: Konieczne jest dokonanie oceny ilości i jakości DNA po jego wyizolowaniu z materiału diagnostycznego [6-8].

E. Rekomendacja: Analiza genetyczna materiału cytologicznego utrwalonego na szkiełku podstawowym powinna być wykonana w rozmazach wybarwionych hemotoksyliną i eozyną $(\mathrm{H}+\mathrm{E})$. Nie rekomenduje się wykorzystywania szkiełek z barwień immunohistochemicznych $[6-8,13,14]$.
Zaleca się, aby identyfikacja komórek nowotworowych i ich lokalizacji w preparacie była dokonywana przez patomorfologa. Postępowanie w laboratorium genetycznym powinno obejmować inkubację preparatu w roztworze ksylenu przez co najmniej 4-6 godzin (optymalnie 12 godzin), usunięcie szkiełka nakrywkowego oraz izolację DNA z komórek usuniętych mechanicznie ze szkiełka podstawowego wyłącznie z miejsc uprzednio oznaczonych przez patomorfologa [6-8, 13, 14].

F. Rekomendacja: Laboratorium genetyczne ma obowiązek ustalenia w drodze wewnętrznej kontroli jakości minimalnego odsetka komórek nowotworowych w preparacie, który zapewnia wiarygodną ocenę mutacji genu EGFR $[6-8,12]$.

Dopuszcza się wykonanie mikrodysekcji komórek nowotworowych z badanego materiału w celu zwiększenia ich odsetka [6-8].

G. Rekomendacja: Do izolacji DNA należy wykorzystywać zestawy odczynników przeznaczone do diagnostyki in vitro (oznaczone symbolem CE-IVD) [6-8, 12].

H. Rekomendacja: Laboratorium genetyczne może wykorzystywać różne techniki oznaczania mutacji genu EGFR, pod warunkiem że zostały one poddane walidacji i dokładnie opisane zgodnie z obowiązującym w Polsce prawem (Ustawa z dnia 18 marca 2011 r. o Urzędzie Rejestracji Produktów Leczniczych, Wyrobów Medycznych i Produktów Biobójczych). Wskazane jest stosowanie metod przeznaczonych do diagnostyki in vitro (oznaczone symbolem CE-IVD) [6-8, 12, 15-17].

Zaleca się korzystanie z technik opartych na reakcji polimerazy łańcuchowej (PCR, polymerase chain reaction), w tym przede wszystkim PCR z analizą w czasie rzeczywistym (RT-PCR, real time polymerase chain reaction). Konieczne jest, aby czułość stosowanej metody analizy mutacji genu EGFR zapewniała wiarygodną analizę materiału tkankowego zawierającego co najmniej 50\% komórek nowotworowych. W takich materiałach dopuszczalna jest analiza genetyczna z wykorzystaniem sekwencjonowania metodą Sangera. Wskazane jest jednak stosowanie bardziej czułych technik molekularnych, umożliwiających identyfikację mutacji genu EGFR w materiale zawierającym co najmniej $10 \%$ komórek nowotworowych $[6-8,15,16]$.

Zaleca się, aby laboratorium nieposiadające technicznych możliwości analizy genetycznej materiału o niskim odsetku komórek nowotworowych niezwłocznie przekazało go do ośrodka referencyjnego, informując o tym również zleceniodawcę [6-8].

I. Rekomendacja: Wymagane jest, aby laboratorium dysponowało metodyką umożliwiającą identyfikację wszystkich mutacji genu EGFR, których częstość występowania wynosi co najmniej 1\% (wśród znanych mutacji genu $E G F R)$ (tab. I) $[6-8,16]$. 
Tabela I.Znane mutacje w genie EGFR (NM_005228.3), których częstość występowania wynosi co najmniej 1\% spośród wszystkich mutacji tego genu [16]

\begin{tabular}{|c|c|c|c|c|}
\hline $\begin{array}{l}\text { Ekson } \\
\text { genu } \\
\text { EGFR }\end{array}$ & $\begin{array}{l}\text { Kodon } \\
\text { genu EGFR }\end{array}$ & Mutacja & Substytucje nukleotydowe & $\begin{array}{l}\text { Szacowana częstość } \\
\text { występowania wśród mutacji } \\
\text { EGFR }(\%)\end{array}$ \\
\hline \multirow[t]{11}{*}{18.} & \multirow[t]{7}{*}{ E709 } & p.E709K & c. $2125 G>A$ & \multirow[t]{7}{*}{1} \\
\hline & & p.E709A & c. $2126 A>C$ & \\
\hline & & p.E709G & c. $2126 A>G$ & \\
\hline & & p.E709V & $c .2126 A>T$ & \\
\hline & & \multirow[t]{2}{*}{ p.E709D } & c. $2127 A>C$ & \\
\hline & & & c. $2127 A>T$ & \\
\hline & & p.E709Q & c. $2125 \mathrm{G}>\mathrm{C}$ & \\
\hline & \multirow[t]{4}{*}{ G719 } & p.G719s & c. $2155 \mathrm{G}>\mathrm{A}$ & \multirow[t]{4}{*}{$2-5$} \\
\hline & & p.G719A & c. $2156 G>C$ & \\
\hline & & p.G719C & c. $2155 G>T$ & \\
\hline & & p.G719D & c. $2156 \mathrm{G}>\mathrm{A}$ & \\
\hline \multirow[t]{15}{*}{19.} & K739 & \multirow{6}{*}{$\begin{array}{l}\text { Insercje } \\
18-p z\end{array}$} & & \multirow[t]{6}{*}{1} \\
\hline & 1740 & & & \\
\hline & P741 & & & \\
\hline & V742 & & & \\
\hline & A743 & & & \\
\hline & 1744 & & & \\
\hline & E746 & \multirow{9}{*}{$\begin{array}{l}\text { Delecje (pz) } \\
9 \\
12 \\
15 \\
18 \\
24\end{array}$} & & \multirow[t]{9}{*}{45} \\
\hline & L747 & & & \\
\hline & & & & \\
\hline & $n / 40$ & & & \\
\hline & E749 & & & \\
\hline & A750 & & & \\
\hline & T751 & & & \\
\hline & S752 & & & \\
\hline & P753 & & & \\
\hline \multirow[t]{9}{*}{20.} & S768 & \multirow{7}{*}{$\begin{array}{l}\text { Insercje (pz) } \\
3 \\
9\end{array}$} & & \multirow[t]{7}{*}{$4-10$} \\
\hline & V769 & & & \\
\hline & D770 & & & \\
\hline & N771 & & & \\
\hline & P772 & & & \\
\hline & $\mathrm{H} 773$ & & & \\
\hline & V774 & & & \\
\hline & S768 & p.S768I & c. $2303 \mathrm{G}>\mathrm{T}$ & $1-2$ \\
\hline & T790 & p.T790M & c. $2369 C>T$ & 2 \\
\hline \multirow[t]{4}{*}{21.} & \multirow[t]{2}{*}{ L858 } & p.L858R & c. $2573 \mathrm{~T}>\mathrm{G}$ & \multirow[t]{2}{*}{40} \\
\hline & & p.L858M & c. $2572 C>A$ & \\
\hline & \multirow[t]{2}{*}{ L861 } & p.L861Q & c. $2582 \mathrm{~T}>\mathrm{A}$ & \multirow[t]{2}{*}{$2-5$} \\
\hline & & p.L861R & c. $2582 \mathrm{~T}>\mathrm{G}$ & \\
\hline
\end{tabular}

pz - pary zasad

J. Rekomendacja:Zaleca się, aby badanie materiału tkankowego w kierunku mutacji T790M genu EGFR (związanej z opornością na IKT EGFR) było wykonywane za pomocą technik o wysokiej czułości, zapewniających wiarygodną analizę materiału zawierającego co najmniej 5\% komórek nowotworowych [6-8].
K. Rekomendacja: Nie zaleca się stosowania reakcji IHC do określenia ekspresji białka EGFR oraz badania liczby kopii genu EGFR techniką fluorescencyjnej lub chromogenicznej hybrydyzacji in situ w celu kwalifikacji do terapii inhibitorami kinazy tyrozynowej EGFR. Nie zaleca się także oznaczania mutacji w genie KRAS w celu kwalifikacji do terapii IKT EGFR [2, 6-8]. 


\section{Wymagania dotyczące technik oraz zakresu badania rearanżacji genu $A L K$}

A. Rekomendacja: Konieczne jest potwierdzenie obecności rearanżacji genu $A L K w$ materiale tkankowym za pomocą techniki FISH, z wykorzystaniem sond dwukolorowych typu „break-apart".Technika IHC może być stosowana jako metoda przesiewowa w kwalifikacji materiałów tkankowych do oznaczenia rearanżacji $A L K$ techniką FISH pod warunkiem uprzedniej walidacji. Zaleca się wykorzystywanie zestawów posiadających certyfikat do diagnostyki in vitro (oznaczone symbolem CE-IVD) [6, 15-19].

B. Rekomendacja: Nie zaleca się stosowania techniki RT-PCR jako metody alternatywnej dla metody FISH w ocenie rearanżacji genu $\operatorname{ALK}[6,18,19]$.

C. Rekomendacja: Zaleca się, aby wybór reprezentatywnego materiału do oceny rearanżacji genu ALK był dokonywany przez patomorfologa zgodnie z zaleceniem zawartym w Rekomendacji C w pkt 4. Konieczne jest też określenie architektury tkanki nowotworowej lub lokalizacji komórek nowotworowych w materiale cytologicznym, jak również jakości tego materiału $[6,18,19]$.

Materiał do badania rearanżacji genu $A L K$ powinien być przechowywany w bloczkach parafinowych (materiał histologiczny lub cytobloki). Nie ma możliwości wiarygodnego oznaczenia rearanżacji genu $A L K$ w preparatach cytologicznych barwionych $\mathrm{H}+\mathrm{E}$ lub w reakcji immunohistochemicznej [6, 18-19].

D. Rekomendacja:Zaleca się, aby badanie rearanżacji genu ALK było wykonywane przez diagnostę laboratoryjnego lub patomorfologa. Warunkiem koniecznym jest równoczesne stosowanie kontroli pozytywnej i negatywnej.

Zaleca się, aby ocena wizualna preparatów była zawsze dokonywana przez dwóch niezależnych obserwatorów posiadających doświadczenie w interpretacji i odczycie wyników badań FISH oraz IHC [6, 18, 19].

Zaleca się, aby w ocenie preparatów uczestniczył patomorfolog posiadający doświadczenie $w$ interpretacji i odczycie wyników barwienia metodą FISH.

E. Rekomendacja: Nie są wymagane badania diagnostyczne w kierunku mutacji genu $A L K$ związanych z nabytą opornością na inhibitory kinazy tyrozynowej ALK $[6,19]$.

\section{Sporządzanie sprawozdań z badania genetycznego oznaczania mutacji genu EGFR i rearanżacji genu $A L K$}

A. Rekomendacja: Konieczne jest, aby sprawozdanie z badania mutacji genu EGFR i rearanżacji genu $A L K$ zawierało wynik badania przedstawiony zgodnie z nomenklaturą Human Genom Variation Society (HGVS) [20] oraz jego interpretację sformułowaną w sposób zrozumiały dla lekarza onkologa lub pulmonologa oraz patomorfologa.

B. Rekomendacja:Zaleca się, aby sprawozdanie z badania genetycznego mutacji genu EGFR zawierało w szczególności: 1) dane umożliwiające niewątpliwą identyfikację pacjenta; 2) dane identyfikujące ośrodek zlecający badanie genetyczne oraz nazwisko lekarza onkologa lub pulmonologa zlecającego badanie; 3) dane identyfikujące pracownię patomorfologii, w której przeprowadzono badanie patomorfologiczne, oraz nazwisko wykonującego to badanie lekarza patomorfologa; 4) numer preparatu skierowanego do badania genetycznego wrazz dokładnym rozpoznaniem patomorfologicznym i odsetkiem komórek nowotworowych zawartych w preparacie oraz wynikami badań immunohistochemicznych, jeżeli były przeprowadzane; 5) opis i czułość techniki wykorzystanej do oceny mutacji genu EGFR; 6) wykaz badanych mutacji; 7) opisową ocenę jakości wyizolowanego DNA; 8) wynik badania genetycznego wraz z interpretacją kliniczną; 9) datę otrzymania materiału i przeprowadzenia badania; 10) podpis diagnosty laboratoryjnego wykonującego oznaczenie oraz osoby autoryzującej wynik: diagnosty laboratoryjnego ze specjalizacją z laboratoryjnej genetyki medycznej, lekarza patomorfologa lub lekarza ze specjalizacją w zakresie genetyki klinicznej. Nie zaleca się, aby sprawozdanie z badania genetycznego zawierało szczegółowe sugestie odnośnie wyboru konkretnego leku ukierunkowanego molekularnie [6-8, 12].

C. Rekomendacje: Sprawozdanie z badania genetycznego rearanżacji genu $A L K$ powinno zawierać dane wymienione w punktach 1-4 oraz 6-7 Rekomendacji B w pkt 6, a także obligatoryjnie opis techniki wykorzystanej do oceny rearanżacji genu $A L K$, informację na temat liczby ocenionych jąder komórkowych (technika FISH) i poziomu ekspresji białka EML4-ALK (technika IHC) [6-8].

\section{Konflikt interesów:}

Paweł Krawczyk: Boehringer Ingelheim,

AstraZeneca, Eli Lilly — komitet doradczy;

Abbott, Roche, Eli Lilly, AstraZeneca,

Boehringer Ingelheim, BMS, MSD — wykład

Joanna Chorostowska-Wynimko:

Boehringer Ingelheim, Novartis - komitet doradczy; Roche, Boehringer Ingelheim, AstraZeneca — wykład Rafal Dziadziuszko: Boehringer Ingelheim, Pfizer — komitet doradczy; Boehringer Ingelheim, Pfizer, Eli Lilly, AstraZeneca - wykład

Jacek Jassem: Roche - grant naukowy;

Boehringer Ingelheim, Eli Lilly, AstraZeneca

— komitet doradczy; Roche — wykład 
Maciej Krzakowski: Boehringer Ingelheim, Eli Lilly — udział w spotkaniu ekspertów

Renata Langfort: Roche, Eli Lilly, AstraZeneca,

Boehringer Ingelheim — wykład

Elżbieta Puacz: brak konfliktu interesów

Bartosz Wasag: Roche - wykład

Kamila Wojas-Krawczyk: brak konfliktu interesów

Prof. dr hab. n. med. Paweł Krawczyk

Pracownia Immunologii i Genetyki,

Katedra i Klinika Pneumonologii,

Onkologii i Alergologii

Uniwersytetu Medycznego w Lublinie

ul. Jaczewskiego 8, 20-954 Lublin

Tel./faks: 817244293

e-mail:krapa@poczta.onet.pl

Przyjęto do druku: 4 lipca 2014 r.

\section{Piśmiennictwo}

1. Obwieszczenie Ministra Zdrowia z dnia 24 lutego 2014 r. w sprawie wykazu refundowanych leków, środków spożywczych specjalnego przeznaczenia żywieniowego oraz wyrobów medycznych (Dz.Urz. MZ 2014, poz. 42).

2. John T, Liu G, Tsao MS. Overview of molecular testing in non-small-cell lung cancer: mutational analysis, gene copy number, protein expression and other biomarkers of EGFR for the prediction of response to tyrosine kinase inhibitors. Oncogene 2009; 28: S14-S23.

3. Travis WD, Brambilla E, Noguchi M i wsp. International Association for The Study of Lung Cancer/American Thoracic Society/European Respiratory Society International Multidisciplinary Classification of Lung Adenocarcinoma. J. Thorac. Oncol. 2011; 6: 244-285.

4. Travis WD, Brambilla E, Rielyl GJ. New pathologic classification of lung cancer: relevance for clinical practice and clinical trials. J. Clin. Oncol. 2013; 31: 992-1001.

5. Szumera-Ciećkiewicz A, OlszewskiW. Miejsce patomorfologii w terapii celowanej raka płuca. Pol. J. Pathol. 2010; 1: 74-79.

6. Lindeman NI, Cagle PT, Beasley MB i wsp. Molecular testing guideline for selection of lung cancer patients for EGFR and ALK tyrosine kinase inhibitors: guideline from the College of American Pathologists, International Association for the Study of Lung Cancer, and Association for Molecular Pathology. J. Thorac. Oncol. 2013; 8: 823-859.

7. Shim HS, Chung JH, Kim Li wsp. Guideline recommendations for EGFR mutation testing in lung cancer: proposal of the Korean Cardiopulmonary Pathology Study Group. Korean J. Pathol. 2013; 47: 100-106.

8. Pirker R, Herth FJ, Kerr KM i wsp. Consensus for EGFR mutation testing in non-small cell lung cancer: results from a European workshop. J. Thorac. Oncol. 2010; 5: 1706-1713.

9. Mirsadraee S, Caulo A, Oswal D i wsp. The 7th lung cancer TNM classification and staging system: Review of the changes and implications. World J. Radiol. 2012; 4: 128-134.

10. Rami-Porta R, Croweley JJ, Goldstrwa P. The revised TNM staging system for lung cancer. Ann. Thorac. Cardiovasc. Surg. 2009; 15: 4-9.

11. Ustawa z dnia 27 lipca 2001 r. o diagnostyce laboratoryjnej (Dz.U. 2001, nr 100, poz. 1083).

12. Rozporządzenie Ministra Zdrowia z dnia 21 stycznia 2009 r. zmieniające rozporządzenie w sprawie standardów jakości dla medycznych laboratoriów diagnostycznych i mikrobiologicznych (Dz.Urz. MZ 2009, nr 22, poz. 128).

13. Navani N, Brown JM, Nankivell M i wsp. Suitability of endobronchial ultrasound-guided transbronchial needle aspiration specimens for subtyping and genotyping of non-small cell lung cancer: a multicenter study of 774 patients. Am. J. Respir. Crit. Care Med. 2012; 185: 1316-1322.

14. Rekhtman N, Brandt SM, Sigel CS i wsp. Suitability of thoracic cytology for new therapeutic paradigms in non-small cell lung carcinoma: high accuracy of tumor subtyping and feasibility of EGFR and KRAS molecular testing. J. Thorac. Oncol. 2011; 6: 451-458.

15. Ellison G, Zhu G, Moulis A i wsp. EGFR mutation testing in lung cancer: a review of available methods and their use for analysis of tumour tissue and cytology samples. J. Clin. Pathol. 2013; 66: 79-89.

16. Skroński M, Szpechciński A, Chorostowska-Wynimko J. Współczesne metody wykrywania mutacji genu EGFR jako czynnika predykcyjnego dla terapii ukierunkowanej molekularnie chorych na niedrobnokomórkowego raka płuca - czy istnieje złoty standard diagnostyczny? Pneumonol. Alergol. Pol. 2014; 82: 311-322.

17. Ustawa z dnia 18 marca 2011 r. o Urzędzie Rejestracji Produktów Leczniczych, Wyrobów Medycznych i Produktów Biobójczych (Dz.U. 2011, nr 82, poz. 451).

18. Wojas-Krawczyk K, KrawczykP, Ramlau R i wsp. The analysis of ALKgene rearangement by fluorescence in situ hybridisation in non-small cell lung cancer patients. Contemp. Oncol. 2013; 17: 484-492.

19. Tsao MS, Hirsch FR, Yatabe Y. IASCL atlas of ALK testing in lung cancer. International Association for the Study of Lung Cancer, Aurora, Colorado, USA. 2013.

20. Human Genetic Variation Society. http://www.hgvs.org. 